\title{
Fruit Retention in Different Litchi Germplasm Influenced by Temperature
}

\author{
Narayan Lal", Alok Kumar Gupta and Vishal Nath \\ ICAR-National Research Centre on Litchi, Muzaffarpur, Bihar, India \\ *Corresponding author
}

\section{A B S T R A C T}

\begin{tabular}{|c|c|}
\hline & $\begin{array}{l}\text { Individual panicles produce hundreds of pistillate flowers, but only a small proportion of } \\
\text { which set fruit and reach at maturity. There are many stages of fruit drop during growth } \\
\text { and development caused by different factors. Different factors are associated with different }\end{array}$ \\
\hline Keywords & ore severely than others. The \\
\hline $\begin{array}{l}\text { Germplasm, Fruit } \\
\text { set, Drop, } \\
\text { Retention, } \\
\text { Temperature. }\end{array}$ & $\begin{array}{l}\text { causes of early fruit drop are numerous including lack of pollination, self-incompatibility, } \\
\text { failure of fertilization, embryo abortion and competition among developing fruit, insect } \\
\text { pests and diseases and climatic condition resulting in internal nutritional and hormonal } \\
\text { imbalances. Varietal differences can also be noticed in the pattern of fruit drop. Therefore, } \\
\text { a trial was carried out at ICAR-NRC on Litchi to see the response of fruit set in different }\end{array}$ \\
\hline Article Info & mplasm and stages of fruit drop in response to temperature. Main emphasis was given \\
\hline $\begin{array}{l}\text { Accepted: } \\
10 \text { October } 2017 \\
\text { Available Online: } \\
10 \text { December } 2017\end{array}$ & $\begin{array}{l}\text { to find out the stages at which maximum drop of fruits takes places. Maximum fruit set } \\
\text { ( } 76.47 \%) \text { was recorded in Ellaichi whereas lowest was observed in shahi during first week } \\
\text { after blooming but maximum fruit retention percentage was reported in Deshi }(1.49) \text { while } \\
\text { lowest was found in dehradoon }(0.3 \%) \text {. The maximum fruit drop was recorded in Ellaichi } \\
(66.18 \%) \text { between } 1^{\text {st }} \text { and } 2^{\text {nd }} \text { week, although fruit drop was very high during this period }\end{array}$ \\
\hline & $\begin{array}{l}\text { range from } 14.72 \text { to } 66.18 \% \text {. Subsequently dropping of fruits were decreased till } \\
\text { harvesting but suddenly increased during the period between } 4^{\text {th }} \text { to } 5^{\text {th }} \text { and } 7^{\text {th }} \text { to } 8^{\text {th }} \text { week } \\
\text { due to fluctuation of maximum and minimum temperature. }\end{array}$ \\
\hline
\end{tabular}

\section{Introduction}

Litchi (Litchi chinensis Sonn.) is the most important fruit crops, belongs to family Sapindaceae, and widely grown in tropical and subtropical regions (Menzel, 1985). It is the most important fruit yielding species and also known as "Queen of fruits. The Litchi is a delicious, juicy fruit of excellent pulp quality. The edible part is arilated mesocarp which is good source of ascorbic acid, sugar, $\mathrm{Ca}$ and phosphorus. Malic acid is the predominant organic acid present in litchi fruit. The top five world litchi producing countries are China, India, Taiwan, Thailand, and Vietnam. India and China account for 91 per cent of the world litchi production. It is grown as major commercial crops in China, Taiwan, Vietnam, Thailand, India, Madagascar, South Africa and Reunion Island whereas Australia, New Zealand, Indonesia, Mauritius, Israel, Spain, the USA and Mexico (Menzel and Simpson, 1994) produces litchi at limited scale. In India, litchi is mainly grown in Bihar, Assam, Tripura, West Bengal, Orissa, Punjab, Uttar Pradesh, 
Uttarakhand, Chhattisgarh, Jharkhand and Himachal Pradesh. It is an important source of income to small farm holders in Bihar and West Bengal. Bihar has largest area of litchi in India but productivity is very much low as compare to other states of India. As the plants require specific climate condition for better flowering and fruiting therefore its area is restricted only few packets and its fruiting period also differ with the growing locations. Litchi produces three types of flower in each panicle and each panicle encompasses more than 100-1000 thousand flowers depending on the age and varieties. Only low percentage of flower develops into fruit and reaches maturity. There are many problems are associated in lowering the productivity of litchi but flower and fruit drop is one of the most important which determine the final production. It is believed that fruit drop is mainly due to an imbalance between the level of IAA and ethylene within fruit tissues and abscission zone (Yuan and Carbaugh, 2007; Yuan and Li, 2008; Li and Yuan, 2008; Zhu et al., 2008, 2010). Fruit drop is genetically, physiologically and environ-mentally regulated but plant stress and premature ethylene production is at the basis of true physiological drop (Robinson et al., 2006 and 2010; Yuan and Carbaugh, 2007; Yuan and Li, 2008; Li and Yuan, 2008; Zhu et al., 2008 and 2010). In litchi, flowering and fruit development stages coincide with summer (high temperature) and during this period environmental factors adversely affect fruit production. ICAR-National Research Centre on Litchi, Muzaffarpur has collected litchi germplasm from different sources and are being grown and maintained in active field gene bank. Centre has large population of litchi which are early, mid and late ripening in nature. The flowering of litchi starts from March and ripe during last week of May and mid-June which coincides with high temperature and low humidity. So the present investigation was carried out to see the effect of temperature on fruit retention in different germplasm and fruit drop stages right from flowering to ripening.

\section{Materials and Methods}

A trial was carried out during 2015 in the field gene bank of ICAR-National Research Centre on Litchi, mushahari, Muzaffarpur. Nine litchi early cultivars (Late large red, Trikolia, Ellaichi, Dehrarose, Deshi, Dehradoon, Rose Scented, Shahi and Ajhauli) having uniform age of 7 years were selected for research. Branches were tagged in four directions (North, South, East and West) and each direction five panicles were selected. Numbers of female flowers were counted from the tagged panicle and data on fruit retention (\%) and fruit drop (\%) were recorded at weekly interval right from blooming to harvesting.

\section{Results and Discussion}

\section{Fruit retention and fruit drop in litchi}

The opening of flower started during midMarch and heavy flower and fruit drop was experienced in litchi. This drop is usually caused by lack of or incomplete pollination or fertilization. The initial drop comprised mostly of unpollinated flowers as the life of individual litchi flowers is very short and many flowers are apparently not pollinated during their receptive period. The same cases of flower drop in ber are also reported by Vashishta and Pareek, (1979). The result presented in table 1 reveals that maximum fruit retention was recorded in Ellaichi (76.47 $\%)$ followed by rose scented $(43.36 \%)$ and trikolia $(43.14 \%)$ whereas minimum was found in Shahi $(22.46 \%)$. The highest fruit retention in Ellaichi might be due to pink or orange colour of thalamus which attracted more number of insects and visiting of more number of insects helped in initial fruit set. 
Table.1 Retention of fruit on the tree after blooming

\begin{tabular}{|l|l|l|l|l|l|l|l|l|l|}
\hline Cultivar & $\begin{array}{l}\mathbf{1}^{\text {st }} \\
\text { week }\end{array}$ & $\begin{array}{l}\mathbf{2}^{\text {nd }} \\
\text { week }\end{array}$ & $\begin{array}{l}\mathbf{3}^{\text {rd }} \\
\text { week }\end{array}$ & $\begin{array}{l}\mathbf{4}^{\text {th }} \\
\text { week }\end{array}$ & $\begin{array}{l}\mathbf{5}^{\text {th }} \\
\text { week }\end{array}$ & $\begin{array}{l}\mathbf{6}^{\text {th }} \\
\text { week }\end{array}$ & $\begin{array}{l}\mathbf{7}^{\text {th }} \\
\text { week }\end{array}$ & $\begin{array}{l}\mathbf{8}^{\text {th }} \\
\text { week }\end{array}$ & $\begin{array}{l}\mathbf{9}^{\text {th }} \\
\text { week }\end{array}$ \\
\hline Late large red & 29.14 & 14.42 & 7.06 & 6.75 & 3.99 & 3.07 & 2.45 & 1.23 & 1.23 \\
\hline Trikolia & 43.14 & 9.66 & 5.92 & 4.82 & 3.74 & 2.18 & 2.18 & 0.93 & 0.93 \\
\hline Ellaichi & 76.47 & 10.29 & 7.35 & 6.76 & 2.35 & 2.35 & 1.76 & 1.18 & 1.18 \\
\hline Dehrarose & 28.16 & 4.14 & 2.07 & 1.95 & 1.15 & 0.92 & 0.69 & 0.69 & 0.69 \\
\hline Deshi & 25.74 & 10.56 & 6.77 & 5.28 & 3.63 & 2.64 & 2.48 & 1.49 & 1.49 \\
\hline Dehradoon & 31.31 & 7.90 & 6.08 & 5.31 & 5.17 & 3.65 & 3.34 & 0.30 & 0.30 \\
\hline Rose Scented & 43.36 & 8.06 & 3.79 & 2.60 & 0.95 & 0.95 & 0.95 & 0.95 & 0.95 \\
\hline Shahi & 22.46 & 2.14 & 2.14 & 1.86 & 1.07 & 1.07 & 1.07 & 0.53 & 0.53 \\
\hline Ajhauli & 60.94 & 11.44 & 5.22 & 4.35 & 1.49 & 1.31 & 0.93 & 0.93 & 0.93 \\
SE (d) & 0.943 & 0.714 & 0.552 & 0.497 & 0.445 & 0.524 & 0.221 & 0.062 & 0.065 \\
\hline C.D. & 2.016 & 1.526 & 1.180 & 1.062 & 0.952 & 1.121 & 0.473 & 0.132 & 0.139 \\
\hline
\end{tabular}

Table.2 Fruit drop percentage at different stage

\begin{tabular}{|l|l|l|l|l|l|l|l|l|}
\hline Cultivar & $\mathbf{1}^{\text {st }} \mathbf{- 2}^{\text {nd }}$ & $\mathbf{2}^{\text {nd }} \mathbf{- 3}^{\text {rd }}$ & $\mathbf{3}^{\text {rd }} \mathbf{- 4}^{\text {th }}$ & $\mathbf{4}^{\text {th }} \mathbf{- 5}^{\text {th }}$ & $\mathbf{5}^{\text {th }}-\mathbf{6}^{\text {th }}$ & $\mathbf{6}^{\text {th }}-\mathbf{7}^{\text {th }}$ & $\mathbf{7}^{\text {th }}-\mathbf{8}^{\text {th }}$ & $\mathbf{8}^{\text {th }} \mathbf{- 9}^{\text {th }}$ \\
\hline $\begin{array}{l}\text { Late large } \\
\text { red }\end{array}$ & 14.72 & 7.36 & 0.31 & 2.76 & 0.92 & 0.62 & 1.22 & 0.00 \\
\hline Trikolia & 33.48 & 3.74 & 1.1 & 1.08 & 1.56 & 0 & 1.25 & 0.00 \\
\hline Ellaichi & 66.18 & 2.94 & 0.59 & 4.41 & 0 & 0.59 & 0.58 & 0.00 \\
\hline Dehrarose & 24.02 & 2.07 & 0.12 & 0.8 & 0.23 & 0.23 & 0 & 0.00 \\
\hline Deshi & 15.18 & 3.79 & 1.49 & 1.65 & 0.99 & 0.16 & 0.99 & 0.00 \\
\hline Dehradoon & 23.41 & 1.82 & 0.77 & 0.14 & 1.52 & 0.31 & 3.04 & 0.00 \\
\hline $\begin{array}{l}\text { Rose } \\
\text { Scented }\end{array}$ & 35.3 & 4.27 & 1.19 & 1.65 & 0 & 0 & 0 & 0.00 \\
\hline Shahi & 20.32 & 0 & 0.28 & 0.79 & 0 & 0 & 0.54 & 0.00 \\
\hline Ajhauli & 49.5 & 6.22 & 0.87 & 2.86 & 0.18 & 0.38 & 0 & 0.00 \\
\hline SE (d) & 0.366 & 0.158 & 0.046 & 0.027 & 0.006 & 0.006 & 0.128 & - \\
\hline C.D. & 0.784 & 0.338 & 0.099 & 0.057 & 0.013 & 0.013 & 0.275 & - \\
\hline
\end{tabular}


Table.3 Weather data during experiment (2015)

\begin{tabular}{|c|c|c|c|c|c|c|}
\hline \multirow{2}{*}{$\begin{array}{l}\text { Standard } \\
\text { Week }\end{array}$} & \multicolumn{5}{|c|}{2015} & \multirow[b]{2}{*}{$\begin{array}{l}\text { Temperature } \\
\text { differences }\end{array}$} \\
\hline & & $\begin{array}{l}\text { Temp } \\
\left({ }^{\circ} \mathrm{C}\right)\end{array}$ & ature & $\begin{array}{l}\text { Relative } \\
\text { humidity } \\
\%\end{array}$ & $\begin{array}{l}\text { Relative } \\
\text { humidity } \\
\%\end{array}$ & \\
\hline \multirow[t]{2}{*}{12} & & Max. & Min. & 0700 hrs & $1400 \mathrm{hrs}$ & \\
\hline & 19-25 Mar( $\left(1^{\text {st }}\right.$ week $)$ & 33.7 & 17.6 & 82 & 43 & 16.1 \\
\hline 13 & $\begin{array}{l}26 \text { Mar-01 AP }\left(2^{\text {nd }}\right. \\
\text { week) }\end{array}$ & 33.28 & 21.28 & 78.85 & 35.28 & 12 \\
\hline 14 & $02-$ AP $8\left(3^{\text {rd }}\right.$ week $)$ & 33.00 & 20.85 & 86.42 & 39.28 & 12.15 \\
\hline 15 & $9-15\left(4^{\text {th }}\right.$ week $)$ & 32.00 & 18.00 & 86.00 & 41.71 & 14 \\
\hline 16 & $16-22\left(5^{\text {th }}\right.$ week $)$ & 35.00 & 21.85 & 81.00 & 36.71 & 13.15 \\
\hline 17 & $23-29\left(6^{\text {th }}\right.$ week $)$ & 33.71 & 23.02 & 83.71 & 43.71 & 10.69 \\
\hline 18 & 30-6 May $\left(7^{\text {th }}\right.$ week $)$ & 35.85 & 23.42 & 83.00 & 46.00 & 12.43 \\
\hline 19 & 7-13 May $\left(8^{\text {th }}\right.$ week $)$ & 41.71 & 25.28 & 75.57 & 37.14 & 16.43 \\
\hline 20 & 14-20May & 37.85 & 26.71 & 76.28 & 36.85 & 11.14 \\
\hline 21 & 21-27 May & 38.57 & 27.57 & 77.71 & 33.28 & 11 \\
\hline
\end{tabular}

The highest final fruit retention was reported in deshi $(1.49 \%)$ and lowest in dehradoon $(0.30 \%)$ at harvesting. There is huge difference in the capacity of fruit retention among the germplasm. In litchi, more female flowers were produced than fruit set and far more fruits were set than develop to maturity. Large numbers of fruits were set initially but only few remain up to maturity. The initial flower and fruit drop is mainly due to improper pollination and failure of fertilization. Fruits were also dropped due to embryo abortion during the stage of fruit development. The later dropping of fruit is mainly due to competition for assimilates. Litchi flower and fruit drop is major problem in young tree. Flowering may be started from the fourth year after planting but such type of flowering having male flowers only.

Mustard et al., (1954), Joubert (1970) and Stern et al., (1995) observed two periods of fruit drop in litchi. Among the fifteen cultivars studied cvs. Bedana, China, Seedless Late and to some extent Piazi were aborted seeded cultivars of which Bedana, China and Piazi exhibited three waves of fruitdrop, whereas Seedless Late showed only two waves of fruit drop. It has been shown by Yuan and Huang (1988) that the multi-waves of fruit abscission in litchi were in parallel with the upsurges of abscissic acid (ABA) in the seed. The major fruit drop period occurs before the peak demand in carbohydrates by the developing fruit. The young green fruit can photosynthesis, however, most of the carbohydrates for the fruit come from current assimilation in the leaves behind the fruit clusters. Reserves in the branches can also be used. Young leaves do not induce fruit abscission unless they develop directly behind the fruit cluster. This generally occurs when fruit set is poor. Generally the number of fruit set is initially very high, but the capacity of fruit retention varies according to the cultivar type and on the level of production of endogenous plant hormones. There are two waves of fruit drop in ber, primarily there is fall of just set fruits due to embryo abortion (Singh and Singh, 1976) and secondly the small developing fruits drop due to formation of premature abscission layer in stalk of nearly ripe fruit. Abscission occurs as a result of natural exhaustion of growth regulators present in fruit or when they cease to flow from their production center because of some 
disorder in tree or climatic conditions (Naidu, 1953).

\section{Temperature and fruit drop}

The data presented in the table 2 reveals fruit drop percentage between weeks starting from fruit set to ripening. The maximum fruit drop was recorded between $1^{\text {st }}$ and $2^{\text {nd }}$ week range from 14.72 to 66.18 percentages. The initial drop comprised mostly of un-pollinated flowers as the life of individual litchi flowers is very short and many flowers are apparently not pollinated during their receptive period. Decreasing in fruit drop was reported during advancing the growth and development of fruits till ripening but abruptly fruit drop increased at two stage; during $4^{\text {th }}-5^{\text {th }}$ week and $7^{\text {th }}-8^{\text {th }}$ week. The fruit drop suddenly increased during $4^{\text {th }}-5^{\text {th }}$ week in all germplasm except trikolia and dehradoon. The suddenly increased in fruit drop due to heavy fluctuation or difference in temperature. This time temperature difference was $14{ }^{\circ} \mathrm{C}$ (Table 3) which might be caused mechanical shock and exerted the formation of abscission layer, whereas, trikolia and dehradoon did not affect due to fluctuation in temperature and this two germplasm seems to be tolerant to temperature. But, fruit drop increased in this germplasm during $5^{\text {th }}-6^{\text {th }}$ week which might be due to other reason. Again heavy drop was recorded during $7^{\text {th }}-8^{\text {th }}$ week due to temperature difference $\left(16.43{ }^{\circ} \mathrm{C}\right)$. The temperature fluctuation has significant role in controlling fruit drop.

It can be concluded that early fruit drop was due to improper pollination and fertilization but dropping of mature fruit was due to temperature fluctuation.

\section{References}

Joubert, A. J. 1970. The Litchi. South Africa Department of Agriculture and
Technical Science Bulletin, 389. 1-22.

Li, J. and Yuan, R. 2008. NAA and ethylene regulate expression of genes related to ethylene biosynthesis, perception and cell wall degradation during fruit abscission and ripening in Delicious apple. J. Plant Growth Regul. 27(2): 283-295.

Menzel, C.M. 1985. Propagation of lychee: a review. Scientia Horticulturae, 25:3148.

Menzel, C.M. and Simpson, D.R. 1994. Lychee. In: Schaffer, B. and Anderson, P.C. (eds), Handbook of Environmental Physiology of Fruit Crops, Vol. II: SubTropical and Tropical Crops, CRC Press, Boca Raton, Florida, pp. 123145.

Mustard, M. J., Liu, S. Y. and Nelson, R. O. 1954. Observations of floral biology and fruit setting in Iychee varieties. Proc Fla. Sta. Hart. Soc. pp. 212-220.

Naidu, N. A. 1953. Immature fruit drop, causes and cures-a review. South Indian Horticulture 1: 3-12.

Robinson, T., Hoying, S., Iungerman, K. and Kviklys. 2010. Retain combined with NAA controls pre-harvest drop of McIntosh apples better than either chemical alone. New York Fruit Quart. 18(3):9-13.

Robinson, T.L., Watkins, C.B., Hoying, S.A., Nock, J.F. and Iungerman, K.I. 2006. Amino ethoxy vinyl glycine and 1Methylcyclopropene effects on "McIntosh" pre-harvest drop, fruit maturation and fruit quality after storage. Acta Hort. 727:473-480.

Singh, U.R. and Singh, N. 1976. Effect of plant regulators on fruit drop, size and quality of ber (Zizyphus mauritiana Lamk.) var. Banarsi. Haryana Journal of Horticultural Sciences. 1976: 5: 1-8.

Stern. R A., Kigel, I., Tomer. E. and Gazil. S. 1995. 'Mauritius' Iychce fruit development and reduced abscission 
after treatment with the auxin 2, 4. 4. TI'. J Amer. Soc. Hart. Sci.. 120 : 65-70. Vashishtha, B. B. and Pareek, O. P. 1979. Flower morphology, fruit set and fruit drop in some ber (Zizyphus mauritiana Lamk.) cultivars. Annals of the Arid Zone, 18: 165-169.

Yuan, R. and Carbaugh, D. 2007. Effects of NAA, AVG, and 1-MCP on ethylene biosynthesis, pre-harvest fruit drop, fruit maturity and quality of "Golden Supreme and Golden Delicious" apples. Hor. Sci. 42(1):101-105.

Yuan, R. and Huang, H. 1988. Litchi fruit abscission: its patterns, effect of shading and relation to endogenous abscissic acid. Scientia Hort. 36: 281-292.

Yuan, R. and Li, J. 2008. Effect of sprayable 1-MCP, AVG, and NAA on ethylene biosynthesis, pre-harvest fruit drop, fruit maturity and quality of "Delicious" apple. Hor Sci. 43(5):1454-1460.

Zhu, H., Beers, E. and Yuan, R. 2008. Aminoethoxyvinylglycine inhibits fruit abscission induced by naphthalene acetic acid and associated relationships with expression of genes for ethylene biosynthesis, perception and cell wall degradation of Delicious apples. J. Am. Soc. Hort. Sci., 133(6):727-734.

Zhu, H., Yuan, R., Greene, D.W. and Beers, E.P. 2010. Effects of 1methylcyclopropene and naphthalene acetic acid on fruit set and expression of genes related to ethylene biosynthesis and perception and cell wall degradation in apple. J. Am. Soc. Hort. Sci. 135(5):402-409.

\section{How to cite this article:}

Narayan Lal, Alok Kumar Gupta and Vishal Nath. 2017. Fruit Retention in Different Litchi Germplasm Influenced by Temperature. Int.J.Curr.Microbiol.App.Sci. 6(12): 1189-1194. doi: https://doi.org/10.20546/ijcmas.2017.612.134 